\title{
Performance of Prilled Urea and Urea Super Granule by Applicators on Yield and Nitrogen Use Efficiency in Boro Rice
}

\author{
A T M S Hossain ${ }^{1}$, F Rahman ${ }^{2}$ and P K Saha ${ }^{3}$
}

\begin{abstract}
A field experiment was conducted on validation of prilled urea (PU) and urea super granule (USG) applied by applicators on yield and nitrogen use efficiency during Boro 2014 season at Bangladesh Rice Research Institute (BRRI) farm, Gazipur (AEZ 28). Six treatment combinations of different N doses and methods of $\mathrm{N}$ application were tested to compare urea-N application by PU and USG applicator for rice yield, $\mathrm{N}$ uptake and $\mathrm{N}$ use efficiency over urea broadcasting. Application of $\mathrm{N}$ as PU or USG through applicator has same effect on grain yield, $\mathrm{N}$ uptake and $\mathrm{N}$ use efficiency compared with urea broadcasting. Statistically similar grain yield were observed with $\mathrm{N}$ application as PU or USG @ $78 \mathrm{~kg} \mathrm{~N} \mathrm{ha}^{-1}$ by applicator which was comparable with urea broadcasting @ $135 \mathrm{~kg}$ $\mathrm{N} \mathrm{ha}^{-1}$. The $\mathrm{N}$ concentration and uptake in both panicle initiation (PI) and maturity stage were higher in USG deep placement than PU deep placement by applicators but the difference was not significant. Although agronomic use efficiency (AUE) of $\mathrm{N}$ was slightly higher in PU than USG applied by applicators but the recovery efficiency (RE) of $\mathrm{N}$ was higher in USG than PU.

Key words: PU, USG, deep placement, applicator, grain yield, AUE, RE.
\end{abstract}

\section{INTRODUCTION}

Nitrogen $(\mathrm{N})$ fertilizer is a major essential plant nutrient and the most yield-limiting nutrient in rice (Oryza sativa L.) cropping systems worldwide (Yoseftabar, 2013, Ladha and Reddy 2003, Fageria et al., 2008). Especially in tropical Asian soils and almost every farmer has to apply the $\mathrm{N}$ fertilizer to get a desirable rice yield (Saleque et al., 2004). Judicious and proper use of $\mathrm{N}$ fertilizer can markedly increase the yield and improve the quality of rice (Chaturvedi, 2005). Both excess and insufficient supply of nitrogen is harmful to the rice crop and may decrease the grain yield. An adequate nitrogen supply can increase as much as $60 \%$ rice production over control (Mikkelsen et al., 1995).

Worldwide, $\mathrm{N}$ recovery efficiency for cereal production (rice, wheat, sorghum, millet, barley, corn, oat and rye) is approximately $33 \%$. The unaccounted $67 \%$ represent a US\$ 15.9 billion annual loss of $\mathrm{N}$ fertilizer (assuming fertilizer soil equilibrium) (Raun and Johnson, 1999). For lowland rice in the tropics recovery efficiency is $30-50 \%$ of applied $\mathrm{N}$ depending on season, yield level, the rate and timing of $\mathrm{N}$ application (Yoshida, 1981; De Datta, 1986). Low recovery of $\mathrm{N}$ fertilizer not only increases cost of production but also may contribute to ground water pollution (Fageria and Barbosa Filho, 2001). So, improved $\mathrm{N}$ fertilizer practices are needed to reduce environmental impacts and increase economic benefits of $\mathrm{N}$ fertilization.

The efficient use of $\mathrm{N}$ fertilizer is recognized as an important factor for rice cultivation, but it has always been a problem to raise the $\mathrm{N}$ utilization rate of the rice plants and to increase the efficiency of absorbed $\mathrm{N}$ for grain production irrespective of $\mathrm{N}$ amount being applied. Low $\mathrm{N}$ fertilizer use or recovery efficiency remains a problem in rice production in Asia (Hussain et al., 2000). The low efficiency of $\mathrm{N}$ fertilizers is 
mainly caused by losses of $\mathrm{N}$ from the soilplant system. Low agronomic efficiency was caused by poor internal efficiency, rather than low supply of soil $\mathrm{N}$ or loss of fertilizer $\mathrm{N}$. Thus often the application of large amount of $\mathrm{N}$ fertilizer by farmers to increase yield of HYV were not justified agronomically and ecologically (Hussain et al., 2005).

In Bangladesh, farmers use $\mathrm{N}$ fertilizer for rice cultivation as prilled urea broadcast or urea super granule (USG) deep placement. Broadcast applied nitrogen fertilizer being washed out of the paddies resulting in reduced nitrogen uptake and river pollution. One solution to this problem is to deep place urea fertilizers as urea granules (Alam et al., 2014). Tarfa and Kiger (2013) reported that USG application with best practices increased $\mathrm{N}$ use efficiency by $40 \%$ and irrigated paddy yield increased up to $20-30 \%$ in Niger State, Nigeria. Likewise, Kuku et al. (2013) and Liverpool-Tasie and Kuku-Shittu (2015) maintained that UDP technology appreciably increased the yield of paddy in Niger State, Nigeria. In the same vein, Vargas (2012) established his study that utilization of UDP led to an increment in rice farmer in Lucia, Ecuador. Rahman and Barmon (2015) clearly established that the utilization of UDP technology significantly increased paddy grain yield in Bangladesh. It is proved that deep placement of USG reduces the $\mathrm{N}$ losses and increases the $\mathrm{N}$ use efficiency. But deep placement of prilled urea is a new concept to us. It may also reduce the $\mathrm{N}$ losses like USG or not. Recently BRRI has developed prilled urea and USG applicator. Therefore, in depth research will be needed to make a comparison study with prilled urea and USG applicators in terms of rice yield and economic benefit.

Considering the above circumstances, a field experiment was conducted to compare urea-N application by PU and USG applicator for rice yield and $\mathrm{N}$ uptake and to estimate the $\mathrm{N}$ use efficiency of PU and USG application by applicators.

\section{MATERIALS AND METHODS}

A field experiment was conducted in Boro 2014 season at the Bangladesh Rice Research Institute (BRRI) farm, Gazipur under the supervision of Soil Science Division in collaboration with Farm Machinery and Post Harvest Technology (FMPHT) Division. The soil of the experimental field was clay loam in texture having $\mathrm{pH}$ 6.5. The other nutrients status was as follows: organic carbon $1.18 \%$, total $\mathrm{N} 0.16 \%$, exchangeable K 0.17 meq/100g soil, available S $19 \mathrm{mg} \mathrm{kg}^{-1}$ and available Zn (DTPA extraction) $4 \mathrm{mg} \mathrm{kg-1}$. The experiment was laid out in a randomized complete block design with three replications. The individual plot size was $3.2 \mathrm{~m} \times 12.8 \mathrm{~m}$.

The treatment combinations were as follows: $\mathrm{T}_{1}=$ Control (no $\mathrm{N}$ fertilizer)

$\mathrm{T}_{2}=$ Hand broadcasting of prilled urea (PU) @ $135 \mathrm{~kg} \mathrm{~N} \mathrm{ha-1} \mathrm{(Recommended} \mathrm{dose)}$

$\mathrm{T}_{3}=$ Hand broadcasting of prilled urea (PU) @ 78 kg N ha-1

$\mathrm{T}_{4}=$ PU application by applicator $@ 78$ kg N ha-1

$\mathrm{T}_{5}=$ USG application by applicator @ $78 \mathrm{~kg} \mathrm{Nha}{ }^{-1}$ (2.7 g/ 4 hills) (Recommended dose)

$\mathrm{T}_{6}=$ Hand broadcasting PU @ 95 kg N ha-1 (70\% of recommended dose of urea broadcasting)

Fertilizer was applied as basal @ 20-60-20$4 \mathrm{~kg} \mathrm{ha}^{-1}$ of $\mathrm{P}, \mathrm{K}, \mathrm{S}$ and $\mathrm{Zn}$ from TSP, MP, gypsum and zinc sulphate respectively. For treatment $T_{2}, T_{3}$ and $T_{6}$ urea was applied in three equal splits; one third as basal, one third at active tillering stage and the rest one third at seven days before panicle initiation (PI) stage. In $T_{4}$ and $T_{5}$, the full dose of prilled urea and USG were applied at three days after transplanting by prilled urea and USG applicators.

Forty-five-day-old seedlings of BRRI dhan29 was transplanted on the last week of January. Irrigation, weeding and other cultural management practices were done equally as per needed. At PI stage, four hills from each plot was collected for counting tiller number, dry weight and nitrogen uptake. At maturity 
the crop was harvested manually in the $2^{\text {nd }}$ week of May in the area of $5 \mathrm{~m}^{2}$ at $15 \mathrm{~cm}$ above ground level for grain yield. However, 16 hills from each plot were harvested at the ground level for yield components and straw yield data. The grain yield was recorded at $14 \%$ moisture content and straw yield as oven dry basis. The tiller and panicle number per meter square were also recorded. Nitrogen concentration and nitrogen uptake by grain and straw were determined by micro-Kjeldahl distillation method.

Nitrogen use efficiency was calculated using the following formulas (Fageria et al., 1997):

Agronomic efficiency $(\mathrm{AE})=\left(\mathrm{G}_{\mathrm{f}}-\mathrm{G}_{\mathrm{u}}\right) / \mathrm{N}_{\mathrm{a}}=\mathrm{kg} \mathrm{kg}^{-1}$ Where, $G_{f}$ is the grain yield of the fertilized plot $(\mathrm{kg}), \mathrm{G}_{\mathrm{u}}$ is the grain yield of the unfertilized plot $(\mathrm{kg})$, and $\mathrm{N}_{\mathrm{a}}$ is the quantity of $\mathrm{N}$ applied (kg).

Recovery efficiency was calculated using the following formulas (FRG, 2012)

Recovery efficiency $(\mathrm{RE})=\left(\mathrm{NU}_{\mathrm{NA}}-\mathrm{NU}_{\mathrm{NO}}\right) / \mathrm{N}_{\mathrm{RN}}$ Where, NU NA $=$ Nutrient uptake $(\mathrm{kg} / \mathrm{ha})$ due to nutrient addition

NU ${ }_{\text {NO }}=$ Nutrient uptake $\left(\mathrm{kg} \mathrm{ha}^{-1}\right)$ due to nutrient omission $\mathrm{N}_{\mathrm{RN}}=$ Rate of nutrient addition $\left(\mathrm{kg} \mathrm{ha}^{-1}\right)$

All the obtained data were analyzed statistically with the software CropStat 7.2 version.

\section{RESULTS AND DISCUSSION}

\section{Dry matter yield and nitrogen uptake at panicle initiation stage}

The tiller number and dry weight at panicle initiation (PI) stage were influenced significantly with application of $\mathrm{N}$ from different forms and methods in Boro season (Table 1). The highest tiller number per meter square was observed in $\mathrm{T}_{2}$ treatment where PU was applied @ $135 \mathrm{~kg} N \mathrm{ha}^{-1}$ as hand broadcasting followed by $\mathrm{T}_{3}$ treatment where PU was applied @ 78 kg N ha-1 on hand broadcasting and the lowest in $\mathrm{N}$ control treatment. In comparison with $\mathrm{N}$ application by PU and USG applicator, no significant difference was observed for tiller production per meter square.

The highest dry weight production at PI stage was observed in $\mathrm{T}_{2}$ treatment followed by $\mathrm{T}_{6}$ and the lowest in $\mathrm{N}$ control. The $\mathrm{T}_{3}, \mathrm{~T}_{4}$ and $T_{5}$ treatment produced statistically similar dry yield as they received same dose of $\mathrm{N}$ (78 $\mathrm{kg} \mathrm{ha}{ }^{-1}$ ).

The $\mathrm{N}$ concentration was statistically similar in plant tissue at PI stage with application of $\mathrm{N}$ from different forms and different methods (Table 1). The highest $\mathrm{N}$ concentration in plant tissue was observed in $\mathrm{T}_{2}$ treatment followed by $\mathrm{T}_{6}$ treatment and the lowest was in $\mathrm{N}$ control treatment. The $\mathrm{N}$ application as USG by applicator gave better $\mathrm{N}$ concentration in plant tissue than $\mathrm{N}$ application as PU by applicator though the difference was statistically identical. A similar trend was observed for $\mathrm{N}$ uptake by all the $\mathrm{N}$ treatments at PI stage of Boro rice.

\section{Grain and straw yield}

The tiller and panicle number per meter square, grain and straw yield were significantly influenced by applying $\mathrm{N}$ from different forms and application methods in Boro rice of BRRI dhan29 (Table 2). The tiller number per $\mathrm{m}^{2}$ in the control plot was only 189. With application of $\mathrm{N}$ from different forms and methods the tiller number per $\mathrm{m}^{2}$ increased significantly over control. The highest tiller number was observed in $T_{2}$ treatment where PU was applied by hand broadcasting as recommended dose followed by $T_{6}$ and $T_{5}$. Significantly lower tiller number was obtained with $\mathrm{N}$ control. The other $\mathrm{N}$ treatment showed statistically similar result for tiller production. A similar trend observed for panicle production per $\mathrm{m}^{2}$ in all $\mathrm{N}$ treatment in Boro season. The 1000 grain weight (TGW) was statistically similar for all $\mathrm{N}$ treatments including $\mathrm{N}$ control. But comparatively higher TGW was observed in USG deep placement $(22.48 \mathrm{~g})$ than PU deep placement (21.99 g) method (Table 2). Islam et al., (2015) also found similar results where insignificant effect of urea applicator was on panicle intensity, panicle length and 1000-grain mass. 
Table 1. Effect of PU and USG on growth, nitrogen concentration and uptake at PI stage of Boro rice, BRRI, Gazipur, 2014.

\begin{tabular}{lcccc}
\hline Treatment & Tiller no. $\mathrm{m}^{-2}$ & Dry wt. $\left(\mathrm{t} \mathrm{ha}^{-1}\right)$ & $\mathrm{N}(\%)$ & $\mathrm{N}$ uptake $\left(\mathrm{kg} \mathrm{ha}^{-1}\right)$ \\
\hline $\mathrm{T}_{1}=\mathrm{N}$ - control & 182 & 1.26 & 1.38 & 17.59 \\
$\mathrm{~T}_{2}=135 \mathrm{~kg} \mathrm{~N} \mathrm{ha}^{-1}$ (as PU by hand broadcasting) & 419 & 3.54 & 1.75 & 63.63 \\
$\mathrm{~T}_{3}=78 \mathrm{~kg} \mathrm{~N} \mathrm{ha}^{-1}$ (as PU by hand broadcasting) & 371 & 2.88 & 1.51 & 43.37 \\
$\mathrm{~T}_{4}=78 \mathrm{~kg} \mathrm{~N} \mathrm{ha}^{-1}$ (as PU by applicator) & 318 & 2.52 & 1.45 & 36.41 \\
$\mathrm{~T}_{5}=78 \mathrm{~kg} \mathrm{~N} \mathrm{ha}^{-1}$ (as USG by applicator) & 338 & 2.76 & 1.65 & 45.81 \\
$\mathrm{~T}_{6}=95 \mathrm{~kg} \mathrm{~N} \mathrm{ha}^{-1}$ (as PU by hand broadcasting) & 345 & 3.19 & 1.70 & 55.10 \\
CV $(\%)$ & 10.5 & 19.7 & 11.9 & 26.0 \\
LSD $(0.05)$ & 63 & 0.97 & 0.34 & 20.52 \\
\hline
\end{tabular}

The grain yield of the $\mathrm{N}$-control plot was only $3.05 \mathrm{t} \mathrm{ha}^{-1}$ and with receiving $\mathrm{N}$ from different sources and methods the grain yield increased significantly in all treatments over $\mathrm{N}$-control (Table 2). The highest grain yield was observed in $\mathrm{T}_{2}$ (5.56 $\mathrm{t} \mathrm{ha-1}$ ) treatment where $\mathrm{N}$ was used @135 kg ha ${ }^{-1}$ as PU hand broadcasting followed by $\mathrm{T}_{4}\left(5.35 \mathrm{t} \mathrm{ha}^{-1}\right)$ where $\mathrm{N}$ was used @78 kg ha-1 as PU by applicator. Similar grain yield was obtained with $\mathrm{T}_{6}(5.35 \mathrm{t}$ ha $^{-1}$ ) where $\mathrm{N}$ was used @ 95 kg ha-1 as PU hand broadcasting. Slightly lower grain yield was observed in $\mathrm{T}_{5}$ treatment (5.21 $\left.\mathrm{t} \mathrm{ha} \mathrm{h}^{-1}\right)$ where $\mathrm{N}$ was applied @ $78 \mathrm{~kg} \mathrm{ha}^{-1}$ as USG by applicator than $\mathrm{T}_{4}$ (PU by applicator). But the difference was not statistically significant. Actually, all the $\mathrm{N}$ treatments produced statistically similar grain yield in Boro season. Islam et al., (2015) found that PU and USG applicators saved $29-32 \%$ of prilled urea without sacrificing grain yield in view of the nitrogen management options. Field trials conducted in farmers' fields across different agro-ecological zones (AEZ) showed that UDP with $25-35 \%$ less urea produced up to $20 \%$ higher yield compared to broadcast PU (Miah et al., 2015; Gregory et al. 2010; IFDC 2013) which was dissimilar to this finding.

IFDC (2007) also reported that deep placement of $\mathrm{N}$ fertilizers had increased rice yield by $22 \%$ over broadcasting and decreased urea use by $47 \%$. Kapoor et al. (2008) reported that significantly higher grain yield was observed with deep placement of NPK briquette compared to broadcast application. A similar trend was observed for straw yield although $\mathrm{T}_{2}$ treatment gave significantly higher straw yield over some treatments may be due to higher $\mathrm{N}$ dose.

In this study, no significant yield differences were observed under $\mathrm{N}$ rates and application methods during the Boro season. Contrary to this study, Huda et al. (2016) who conducted an experiment and reported increased yield with increasing $\mathrm{N}$ rates from 78 to $156 \mathrm{~kg} \mathrm{~N} \mathrm{ha-1} \mathrm{during} \mathrm{the} \mathrm{Boro} \mathrm{season,}$ particularly in broadcast PU.

Table 2. Effect of PU and USG on yield and yield components of Boro rice, BRRI, Gazipur, 2014.

\begin{tabular}{|c|c|c|c|c|c|}
\hline Treatment & $\begin{array}{c}\text { Tiller no. } \\
\mathrm{m}^{-2}\end{array}$ & $\begin{array}{l}\text { Panicle } \\
\text { no. } \mathrm{m}^{-2}\end{array}$ & $\begin{array}{l}1000 \text { grain } \\
\text { weight (g) }\end{array}$ & $\begin{array}{l}\text { Grain } \\
\text { yield } \\
\left(\mathrm{t} \mathrm{ha}^{-1}\right)\end{array}$ & $\begin{array}{l}\text { Straw } \\
\text { yield } \\
\left(\mathrm{t} \mathrm{ha}^{-1}\right)\end{array}$ \\
\hline $\mathrm{T}_{1}=\mathrm{N}-\mathrm{control}$ & 189 & 183 & 21.91 & 3.05 & 2.97 \\
\hline $\mathrm{T}_{2}=135 \mathrm{~kg} \mathrm{~N} \mathrm{ha}^{-1}$ (as PU by hand broadcasting) & 330 & 312 & 21.83 & 5.56 & 5.76 \\
\hline $\mathrm{T}_{3}=78 \mathrm{~kg} \mathrm{~N} \mathrm{ha}^{-1}$ (as PU by hand broadcasting) & 280 & 273 & 22.35 & 5.17 & 5.11 \\
\hline $\mathrm{T}_{4}=78 \mathrm{~kg} \mathrm{~N} \mathrm{ha}^{-1}$ (as PU by applicator) & 277 & 271 & 21.99 & 5.35 & 5.55 \\
\hline $\mathrm{T}_{5}=78 \mathrm{~kg} \mathrm{~N} \mathrm{ha}^{-1}$ (as USG by applicator) & 289 & 276 & 22.48 & 5.21 & 5.03 \\
\hline $\mathrm{T}_{6}=95 \mathrm{~kg} \mathrm{~N} \mathrm{ha}^{-1}$ (as PU by hand broadcasting) & 290 & 282 & 22.37 & 5.35 & 5.25 \\
\hline CV (\%) & 9.4 & 9.0 & 2.1 & 5.2 & 6.2 \\
\hline LSD $(0.05)$ & 46.92 & 43.36 & NS & 0.47 & 0.56 \\
\hline
\end{tabular}




\section{Nitrogen uptake}

The grain and straw $\mathrm{N}$ concentrations and $\mathrm{N}$ uptake were significantly influenced by different doses and methods of $\mathrm{N}$ application (Table 3). The highest $\mathrm{N}$ concentration was observed in $T_{2}$ treatment followed by $T_{6}$ treatment. The $\mathrm{N}$ concentration in grain of USG treatment was higher than PU deep placement. A similar trend was observed for straw $\mathrm{N}$ concentration in all treatments.

The $\mathrm{N}$ uptake by grain and straw varied significantly with application of $\mathrm{N}$ in Boro season. The $\mathrm{N}$ uptake by grain in $\mathrm{T}_{2}$ treatment was significantly higher than $\mathrm{N}$-control, $\mathrm{T}_{3}, \mathrm{~T}_{4}$ and $T_{5}$ treatment but $T_{6}$ treatment produced statistically similar $\mathrm{N}$ uptake like $\mathrm{T}_{2}$. Mostly similar trend was observed for straw $\mathrm{N}$ uptake by rice at maturity stage.

The total nitrogen uptake (TNU) by rice at maturity stage showed significant variation with receiving different forms and method of $\mathrm{N}$ in Boro rice (Table 3). The highest Nitrogen uptake was obtained in $\mathrm{T}_{2}$ treatment where recommended dose of $\mathrm{N}$ was applied and the lowest was found in control. The deep placement of PU and USG had no significant difference for $\mathrm{N}$ uptake in Boro rice of BRRI dhan29. Actually the crop slightly suffered in nitrogen deficiency at the PI stage particularly in the treatments of urea deep placement by applicators and the lower dose of $\mathrm{N}$ was applied.

\section{Nitrogen use efficiency}

Table 4 describes the agronomic use efficiency (AUE) and recovery efficiency (RE) of N. The AUE in the recommended dose of PU $(135 \mathrm{~kg}$ $\mathrm{N}$ ha-1) was $18.56 \mathrm{~kg}^{-1}$ and in $70 \%$ of recommended dose of PU (95 kg N ha-1) it was $24.24 \mathrm{~kg}^{-1}$. The deep placement of PU and USG increased the AUE of N. Significantly higher AUE were observed using $78 \mathrm{~kg} \mathrm{~N} /$ ha than $135 \mathrm{~kg} \mathrm{~N} \mathrm{ha}{ }^{-1}$. The highest $\mathrm{N}$ use efficiency was observed in $\mathrm{T}_{4}$ treatment $\left(29.46 \mathrm{~kg} \mathrm{~kg}^{-1}\right)$ where PU was applied by applicator followed by $T_{5}$ treatment (27.68 $\left.\mathrm{kg} \mathrm{kg}^{-1}\right)$ where USG was applied by applicator but the difference was not significant.

Among the treatments, recovery efficiency (RE) of applied $\mathrm{N}$ varied from $40.21 \%$ to $50.40 \%$. The highest RE of $50.40 \%$ was obtained in $\mathrm{T}_{5}$ (78 kg N ha-1 by USG applicator) and the lowest in $\mathrm{T}_{2}\left(135 \mathrm{~kg} \mathrm{~N} \mathrm{ha}^{-1}\right.$ by PU hand broadcasting) though the difference was statistically identical.

Deep placement of USG increased nitrogen use efficiency by keeping most of the urea nitrogen in the soil, close to plant roots and out of the irrigation water (IFDC, 2007). Kapoor et al., (2008) also observed that significantly higher $\mathrm{N}$ uptake and $\mathrm{N}$ use efficiency with deep placement of $\mathrm{N}$ compared to broadcast application.

Table 3. Effect of PU and USG on N concentration and N uptake by Boro rice, BRRI, Gazipur, 2014.

\begin{tabular}{|c|c|c|c|c|c|}
\hline Treatment & GN (\%) & SN $(\%)$ & GNU (kg ha-1) & SNU (kg ha-1) & $\begin{array}{c}\text { TNU (kg } \\
\text { ha-1) }^{-1}\end{array}$ \\
\hline $\mathrm{T}_{1}=\mathrm{N}-$ control & 0.87 & 0.49 & 26.66 & 14.43 & 41 \\
\hline $\mathrm{T}_{2}=135 \mathrm{~kg} \mathrm{~N}^{-1}$ (as PU by hand broadcasting) & 1.08 & 0.61 & 60.24 & 35.13 & 95 \\
\hline $\mathrm{T}_{3}=78 \mathrm{~kg} \mathrm{~N} \mathrm{ha}^{-1}$ (as PU by hand broadcasting) & 0.95 & 0.54 & 49.23 & 27.62 & 77 \\
\hline $\mathrm{T}_{4}=78 \mathrm{~kg} \mathrm{~N} \mathrm{ha}^{-1}$ (as PU by applicator) & 0.89 & 0.51 & 47.88 & 27.99 & 76 \\
\hline $\mathrm{T}_{5}=78 \mathrm{~kg} \mathrm{~N} \mathrm{ha}^{-1}$ (as USG by applicator) & 1.00 & 0.56 & 52.25 & 28.16 & 80 \\
\hline $\mathrm{T}_{6}=95 \mathrm{~kg} \mathrm{~N} \mathrm{ha}^{-1}$ (as PU by hand broadcasting) & 1.05 & 0.59 & 56.08 & 30.58 & 87 \\
\hline $\mathrm{CV}(\%)$ & 5.2 & 9.5 & 6.9 & 10.4 & 6.0 \\
\hline LSD (0.05) & 0.09 & 0.09 & 6.13 & 5.17 & 8.32 \\
\hline
\end{tabular}


Table 4. Effect of PU and USG on agronomic use efficiency and recovery efficiency of $\mathrm{N}$ applied in Boro rice, BRRI, Gazipur, 2014.

\begin{tabular}{lcc}
\hline Treatment & $\begin{array}{c}\text { Agronomic use efficiency } \\
\text { of N applied }\left(\mathrm{kg}^{-1}\right)\end{array}$ & $\begin{array}{c}\text { Recovery efficiency } \\
\text { of N applied (\%) }\end{array}$ \\
\hline $\mathrm{T}_{1}=\mathrm{N}-$ Control & - & - \\
$\mathrm{T}_{2}=135 \mathrm{~kg} \mathrm{~N} \mathrm{ha}^{-1}$ (as PU by hand broadcasting) & 18.56 & 40.21 \\
$\mathrm{~T}_{3}=78 \mathrm{~kg} \mathrm{~N} \mathrm{ha}^{-1}$ (as PU by hand broadcasting) & 27.17 & 45.84 \\
$\mathrm{~T}_{4}=78 \mathrm{~kg} \mathrm{~N} \mathrm{ha}^{-1}$ (as PU by applicator) & 29.46 & 44.59 \\
$\mathrm{~T}_{5}=78 \mathrm{~kg} \mathrm{~N} \mathrm{ha}^{-1}$ (as USG by applicator) & 27.68 & 50.40 \\
$\mathrm{~T}_{6}=95 \mathrm{~kg} \mathrm{~N} \mathrm{ha}^{-1}$ (as PU by hand broadcasting) & 24.24 & 47.97 \\
CV $(\%)$ & 13.6 & 13.10 \\
LSD $(0.05)$ & 6.49 & 11.33 \\
\hline
\end{tabular}

\section{CONCLUSIONS}

The recommended dose of urea by hand broadcasting @135 kg N ha-1 produced the highest yield but the yield was statistically similar to the application of N as PU or USG @ $78 \mathrm{~kg} \mathrm{ha}^{-1}$ by applicators. However, it would save around $57 \mathrm{~kg} \mathrm{~N}$ ha-1 $^{-1}$ as well as protect the soil from environmental pollution. Moreover, AUE and RE of $\mathrm{N}$ were found highest with the application of $\mathrm{N}$ as PU or USG by applicators than that of recommended dose of urea.

\section{REFERENCES}

Adjornon, S G and L S O Liverpool-Tasie. 2014. Spatial dependence in the utilization of the urea deep placement for rice production in Niger State, Nigeria: A Bayesian Spatial Autoregressive Profit Estimation Approach. Selected Paper prepared for presentation at the Agricultural and Applied Economics Association's 2014 AAEA Annual Meeting, Minneapolis, MN, July 27-29, 2014.

Alam, M S, D K Nath and F Amin. 2014. The effect of nitrogen management practices on yield and yield attributes of T. Aus rice under a tidal ecosystem. Proceedings of the 4th International Rice Congress, October 28-31, 2014, Bangkok, Thailand.

Bandaogo, A, F Bidjokazo, S Youl, E Safo, R Abaidoo and P Andrews. 2015. Effect of fertilizer deep placement with urea super granule on nitrogen use efficiency of irrigated rice in Sourou Valley (Burkina Faso). Nutrient Cycling Agroecosyst, 102:79.

Chaturvedi, I. 2005. Effect of nitrogen fertilizers on growth, yield and quality of hybrid rice. J. Central European Agric. 6: 611-618.

De Datta, S K. 1986. Improving nitrogen fertilizer efficiency in lowland rice in tropical Asia. Fert. Res. 9: 171-186.
Fageria, N K and M P Barbosa Filho. 2001. Nitrogen use efficiency in lowland rice genotypes. Communications in soil science and plant analysis. 32(13\&14): 2079-2089.

Fageria, N K, A B Santos and V A Cutrim. 2008. Dry matter and yield of lowland rice genotypes as influence by nitrogen fertilization. J. Plant Nutr. 31: 788-795.

Fageria, N K, V C Baligar and C A Jones. 1997. Growth and mineral nutrition of field crops. 2nd Ed., Marcel Dekker, Inc., New York.

FRG (Fertilizer Recommendation Guide). 2012. BARC (Bangladesh Agricultural Research Council), Farmgate, Dhaka. Pp. 50-51.

Gregory, D I, S M Haefele, R J Buresh and U Singh. 2010. Fertilizer use, markets, and management. In: Pandey, S. et al. (Eds.), Rice in the Global Economy: Strategic research and policy issues for food security. International Rice Research Institute, pp 231-263.

Huda, A, Y K Gaihre, M R Islam, U Singh, Md R Islam, J Sanabria, M A Satter, H Afroz, A Halder and M Jahiruddin. 2016. Floodwater ammonium, nitrogen use efficiency and rice yields with fertilizer deep placement and alternate wetting and drying under tipple rice cropping systems. Nutr Cycl Agroecosyst. DOI: $10.1007 /$ s10705-015-9758-6.

Hussain, F, K F Bronson, Y Sing, B Sing and S Peng. 2000. Use of Chlorophyll meter sufficiency indices for nitrogen management of irrigated rice in Asia. Agron. J., 92: 775-779.

Hussain, M F, S K White, J L Elahi, N Sultana, M H K Choudhury, Q K Alam, J A Roller and J L Gaunt. 2005. The efficiency of nitrogen fertilizer for rice in Bangladeshi farmers' field. Field Crop Res. 93: 94-107.

IFDC. 2007. Mitigating poverty and environmental degradation through nutrient management in South Asia. IFDC Report, March 2007. International Fertilizer Development Centre.

IFDC. 2013. Fertilizer deep placement. IFDC solutions. International Fertilizer Development Center (IFDC), Muscle Shoals, AL 35662 USA, p 6 http://www.ifdc.org/get attachment/1c7e9b2e37b3-4ea4-93c1-318013dc3ce9/ FDP.pdf. 
Islam, A K M S, M A Rahman, A K M Lutfor Rahman, M T Islam and M I Rahman. 2015. Performance evaluation of push type prilled urea applicator in rice cultivation. Bangladesh Rice J. 19(2): 71-81.

Kapoor, V, U Singh, S K Patil, H Magre, L K Shrivastava, V N Mishra, R O Das, V K Samadhiya, J Sanabria and $\mathrm{R}$ Diamond. 2008. Rice growth, grain yield and floodwater nutrient dynamics as affected by nutrient placement method and rate. Agronomy Journal. 100(3):526-536.

Ladha, J K and P M Reddy. 2003. Nitrogen fixation in rice system: state of knowledge and future prospects. Plant Soil 252:151-167.

Miah, Md A M, Y K Gaihre, G Hunter, U Singh and S A Hossain. 2015. Fertilizer deep placement increases rice production and economic returns in southern Bangladesh. Agron J. DOI:10.2134/agronj2015.0170.

Mikkelsen, D S, G R Jayaweera and D E Rolston. 1995. Nitrogen fertilizer practices of lowland rice culture. In: Nitrogen fertilization and the environment. pp. 171-223.

Rahman, S and Barmon, B K 2015. Productivity and efficiency impacts of urea deep placement technology in modern rice production: An empirical analysis from Bangladesh. The Journal of Developing Areas.

Raun, W R and G V Johnson. 1999. Improving nitrogen use efficiency for central production. Agron. J. 91: 357363.

Saleque, M A, U A Naher, N N Choudhury and A T M S Hossain. 2004. Variety-specific nitrogen fertilizer recommendation for lowland rice. Communication in Soil Sci. 35: 1891-1903.

Vargas, S A M. 2012. Cost-benefit analysis for the utilization of the urea deep placement technology by the rice farmers of Daule and Santa Lucia, Ecuador. A thesis presented to the graduate school of the University of Florida for the degree of Master of Science. .http:/ / ufdc.ufl.edu/UFE0044808/00001

Yoseftabar, S. 2013. Effect of nitrogen management on panicle structure and yield in rice (Oryza sativa L.). Int J Agri Crop Sci 5(11):1224-1227.

Yoshida, S. 1981. Fundamentals of rice crop science. IRRI, Los Banos. Philippines. pp. 235-237. 